\title{
The current situation and countermeasures for conservation of ancient and famous trees in Laoshan, Qingdao, China
}

\begin{abstract}
Xuliang Zhang ${ }^{*}$ (iD Lihua Wang ${ }^{2}$ (D) Zheng Liu ${ }^{2}$ (D) Tao Zheng ${ }^{2}$ (D) Yinghui Cao ${ }^{1}$ Xiujun Liu ${ }^{1}$
${ }^{1}$ School of Tourism and Geography Science, Qingdao University, Qingdao 266071, Shandong, China, E-mail: Geo_zhang@163.com. ${ }^{*}$ Corresponding author.

${ }^{2}$ Construction Engineering College, Qingdao Agricultural University, Qingdao, Shandong, China.

ABSTRACT: This study aimed to examined the characteristics of ancient and famous trees in Laoshan District, Qingdao City, Shandong Province, China, including species composition, number of individuals, origin, distribution, and age structure, to highlight the values of inheriting history and culture, improving urban environment, protecting regional biodiversity, promoting tourism economy and so on. The analyses was made through field surveys and quantitative analyses of statistical data and relevant literature, The main issues in their conservation are investigated and priority conservation measures are proposed. Results showed that there are 290 ancient and famous trees, comprising 42 species, 34 genera, and 26 families. These included four types of ancient and famous trees with different origins, namely religious trees planted by Buddhists, naturally preserved wild trees, trees with agricultural backgrounds for providing food or used as offerings, and exotic trees introduced from other places. There are relatively more local species and comparatively more elder trees. Ancient and famous trees are distributed in large numbers in Mountain Lao Scenic Area and many of them fall into temperate genera. Currently, ancient and famous tree conservation in Laoshan District is challenging because of issues such as habitat deterioration, severe effects of natural hazards, pests and diseases, weakening physiological function, and inadequate management. Based on all these analyses, countermeasures are proposed, which include regularly inspecting ancient and famous trees, restoring their habitats, reinforcing pest and disease controls, promoting studies on conservation technologies, improving management practices, increasing grants, and reforming the ownership system of ancient and famous trees. Key words: origins, tree ages, distribution, growth condition, conservation.
\end{abstract}

A situação atual e contramedidas para a conservação de árvores antigas e famosas em Laoshan, Qingdao, China

RESUMO: No presente estudo foram examinadas as características, incluindo espécies, número, origem, distribuição e estrutura etária de árvores antigas e famosas no distrito de Laoshan, cidade de Qingdao, província de Shandong, China. Para tal empregou-se um levantamento de campo e análises quantitativas de dados estatísticos e literatura relevante disponível. As principais questões relativas à sua conservação foram investigadas e medidas de conservação prioritárias são propostas. Os resultados mostraram que existem 290 árvores antigas e famosas, compreendendo 42 espécies, 34 gêneros e 26 familias. Estes incluíram quatro tipos de árvores antigas e famosas com origens diferentes, como as árvores religiosas, árvores silvestres naturalmente preservadas, árvores agrícolas ou usadas como oferendas, e árvores exóticas originarias de outros locais. Há relativamente mais espécies nativas e comparativamente mais árvores mais velhas. Muitas árvores antigas e famosas são distribuidas na área cênica Mountain Lao e muitas delas pertencem a gêneros temperados. Atualmente, a conservação de árvores antigas e famosas no Distrito de Laoshan é desafiadora devido a questões como deterioração do habitat, efeitos severos de perigos naturais, pragas e doenças, enfraquecimento da função fisiológica e manejo inadequado. Medidas foram propostas, por exemplo, inspecionar regularmente árvores antigas e famosas, restaurar seus habitats, reforçar controles de pragas e doenças, promover estudos sobre tecnologias de conservação, melhorar práticas de manejo, aumentar subsidios e reformar o sistema de propriedade de árvores antigas e famosas.

Palavras-chave: árvores antigas e famosas, origens, idade das árvores, distribuição, condição de crescimento, conservação.

\section{INTRODUCTION}

Ancient and famous trees refer to trees no less than 100 years old that have survived the course of human history, or trees with important scientific, cultural, or commemorative significance (NATIONAL AFFORESTATION COMMITTEE OF CHINA AND STATE FORESTRY ADMINISTRATION OF
CHINA, 2001). Specifically, ancient trees are aged 100 years or more, whereas famous trees cover friendship trees planted or gifted by foreign national leaders, commemorative trees planted by national leaders for special events, trees grown as embellishments of important attractions at scenic spots, trees associated with historical legends or anecdotes, and trees designated as rare or endangered species by the 
government (MINISTRY OF CONSTRUCTION OF THE PEOPLE'S REPUBLIC OF CHINA, 2000).

Ancient and famous trees are generally believed to be witnesses to history, constituent elements of the landscape at scenic spots, and targets for germplasm resource conservation for rare and endangered plant species. Moreover, they provide essential biological evidence for research on regional climate and ecological changes. Hence, they are of high ecological, scientific, historical, cultural, and aesthetic value (GOUGH et al., 2015, MOHAMAD et al., 2013).

For a long time, the Chinese Government has launched numerous surveys, and conservation and research projects, on these trees. Early in 1963, the State Council of the People's Republic of China (PRC) established the Urban Greenery Regulations. In 2000, the Ministry of Construction of the PRC set up the Management Acts of Urban Ancient and Famous Trees Protection. One year later, in 2001, the National Afforestation Committee and the State Forestry Administration of the PRC initiated a national survey of ancient and famous trees. Since the 1990s, researchers in China and abroad have carried out various studies on the value, species composition, numbers of individuals, and distribution of ancient and famous trees, survey and documentation methodology, current conservation situations and challenges, and detailed technical measures to preserve and rejuvenate them (MATHAUX et al., 2016, MARRIS, 2016, NUGTEREN, 2016, AKTER et al., 2015, MARTIN, 2013, ZHANG et al., 2013, ZHU et al., 2013, LIU et al., 2008).

During the process of urbanization in the past decades, numerous ancient and famous trees have been preserved in Laoshan District, Qingdao City. Nevertheless, at present, there are many challenges in their conservation in the region. For example, all these trees are influenced by regional climatic changes, such as prolonged droughts. Some of them are subject to excessively dense rhizosphere soils as well as low water and air permeability of the ground and soils due to urbanization and tourism developments. Some have suffered severely as a result of natural hazards, namely typhoons, lightning strikes, rainstorms, droughts, cold damage, forest pests, and diseases. For instance, some ancient trees such as Sophora japonica and Sabina chinensis are under threat from forest pests such as aphids, which leads to deterioration of the habitat of these trees (GAO \& ZHANG, 2018). Some of these trees have weakened vitality and reduced physiological function (YUAN \& WANG, 2018). Furthermore, in terms of management, the main challenges involved vaguely defined conservation responsibilities, weak law enforcement, lack of routine maintenance, and obsolete conservation techniques (ZHANG et al., 2017, COMPILING COMMITTEE OF ANCIENT AND FAMOUS TREES IN LAOSHAN DISTRICT, 2015).

This paper examined the current situation and the challenges of ancient and famous tree conservation in Laoshan District, Qingdao City, and proposed effective countermeasures. These measures are important for inheriting the history and culture borne by these ancient and famous trees, improving urban environments, protecting regional biodiversity, and resolving the homogenization of urban artificial vegetation resulting from urban greening. In the long run, they will play a significant part in promoting tourism development in the region discussed and constructing ecological gardens in urban areas (MCKINNEY, 2006).

\section{STUDY AREA AND METHODOLOGY}

\section{Study area}

Laoshan District $\left(120^{\circ} 22^{\prime}-120^{\circ} 43^{\prime} \mathrm{E}\right.$, $\left.35^{\circ} 23^{\prime}-36^{\circ} 03^{\prime} \mathrm{N}\right)$ is located in the eastern part of Qingdao City and borders the Shinan District and the Shibei District to the west, and the Licang District, the Chengyang District, and the Jimo District to the north (Figure 1). At the Southeast of the district lies the Yellow Sea. The district's width from West to East and length from South to North are $27.3 \mathrm{~km}$ and $31.3 \mathrm{~km}$ respectively. Its total land and water area are $395.8 \mathrm{~km}^{2}$ and $3700 \mathrm{~km}^{2}$ respectively, and its coastline is $103.7 \mathrm{~km}$ long. The terrain is high in the east and low in the west, with a maximum elevation of $1132.7 \mathrm{~m}$ at Jufeng, the highest peak of Laoshan Mountain (JU et al., 2012). The district mostly consists of hills, uplands, and plains, each of which corresponds to $54.8 \%, 19.6 \%$, and $25.6 \%$ of the total area respectively. Laoshan District is characterized in climate by a warm-temperate-continental monsoon with strong oceanic influences, which means it is warm in winter and cool in summer. Specifically, abundant precipitation, small differences between day and night temperatures, prolonged frost-free periods, and high humidity are typical features of this district. There are two main types of soils, namely brown soils and cinnamon soils. Brown soils are mostly distributed in hilly uplands and their parent material is often granite, with significant variations in their thickness and texture. Cinnamon soils, usually reported in plains adjacent to mountains, are relatively thick, permeable, and fertile. Thanks 


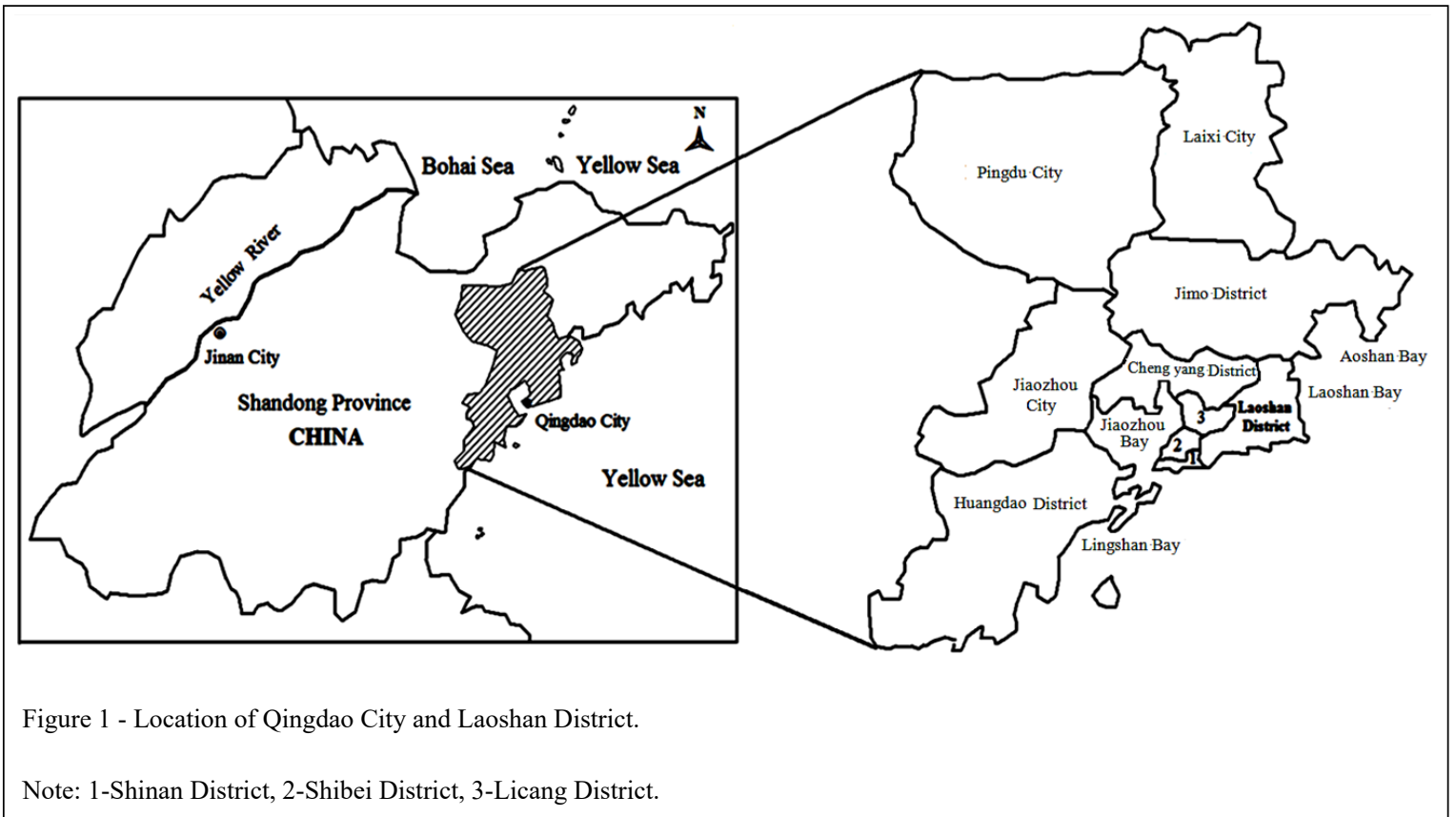

to the mild, humid climate, and relatively high soil fertility, Laoshan District is suitable for the growth, introduction, and domestication of many plant species, from either the south or the north. As a result, a variety of vegetation types coexist today, namely forest, shrub lands, grasslands, desert plant communities, halophyte communities, and agricultural cultivated plants (HISTORY AND ANNALS OFFICE OF QINGDAO, 1999).

\section{Methodology}

The overall survey on ancient and famous trees of Laoshan District was conducted by Administration for Agriculture \& Forestry of Laoshan District and Laoshan Tree Farm in 2013. By analyzing the data collected in the survey, the authors studied the characteristics of the ancient and famous trees in Laoshan District. Other methods included added field surveys, interviews, literature analyses, geographic information technology, and mathematical statistics, etc. Analysis centered on such factors as the origins, family and genus composition, floristic composition, quantitative characteristics, age structure, distribution, growth condition of the ancient and famous trees and other associated factors. The current challenges in their conservation were also studied, involving wilting, dying, rotting of branches, and formation of tree holes, and types and occurrence of pests and diseases (ZHANG et al., 2017). The age of ancient and famous trees are mainly determined by analyzing literature, interviewing local residents, and comparing tree diameters at breast height with others of the same species (COMPILING COMMITTEE OF ANCIENT AND FAMOUS TREES IN LAOSHAN DISTRICT, 2015). Based on the above mentioned analyses, the principal countermeasures are proposed, aiming to protect the ancient and famous trees in the region.

\section{RESULTS}

Origins of ancient and famous trees in Laoshan District The ancient and famous trees in Laoshan District were produced by various natural and anthropogenic factors, such as advantageous natural environments, enduring religious, agricultural and offering cultures, tree worship by indigenous people, natural dispersion of trees, and artificial introduction of exotic species, etc (YUAN \& WANG, 2018). The district is characterized by a relatively large number of old, first-class ancient trees aged 500 years or more, historical legend- or anecdote-related ancient and famous trees, and exotic trees introduced from other places as well as a relatively concentrated distribution. Based on their origins, ancient and famous tress in Laoshan District are classified into four types, namely religious trees, naturally dispersed and preserved wild trees, trees with agricultural backgrounds or used as offerings, and exotic trees introduced elsewhere. In terms of quantity, the first three

Ciência Rural, v.49, n.10, 2019. 
groups are in the majority and the fourth group makes up a small percentage (ZHANG et al., 2017, COMPILING COMMITTEE OF ANCIENT AND FAMOUS TREES IN LAOSHAN DISTRICT, 2015, HISTORY AND ANNALS OFFICE OF QINGDAO, 2007).

Mostly distributed in the Laoshan scenic area, ancient and famous trees of religious origin are dominant in Laoshan District. Laoshan Mountain is one of the birthplaces of Taoism - one principle of prohibiting killing - and Taoists believe that trees in temples signify the rise and fall of the temples (HISTORY AND ANNALS OFFICE OF QINGDAO, 2007). Consequently, Taoists tried their best in the conservation of ancient and famous trees of religious origin when managing the temples in Laoshan Mountain since Western Han Dynasty. When the Taiqing Temple and the Shangqing Temple were first built; and subsequently renovated, trees that are often long-lived and less susceptible to pests and diseases were planted to decorate the gardens. Examples are Ginkgo biloba, S. chinensis, Platycladus orientalis, Celtis sinensis and Chimonanthus praecox. Taoists saved the ancient and famous trees in temple gardens from being felled. Currently, there are 107 ancient and famous trees of religious origin preserved in the Taiqing Temple (COMPILING COMMITTEE OF ANCIENT AND FAMOUS TREES IN LAOSHAN DISTRICT, 2015).

Ancient and famous trees of natural origin account for approximately $10 \%$ of the total in Laoshan District. One of them is Quercus acutissima and its distribution is relatively concentrated. A population of 15 Q. acutissima individuals aged over 120 years old is congregated in the Huayan Temple and its surrounding area. Other wild ancient and famous trees exist in the form of a single plant or separate small populations naturally distributed on Laoshan Mountain. For example, there stands one 210-yearold Sapium sebiferum individual in the Shenshui Spring of the Taiqing Temple, three C. bungeana individuals in Diaolongzui Village, Wanggezhuang Residential District and the Huayan Temple scenic area, as well as one 170-year-old $Q$. acutissima individual in the Taiqing Temple scenic area and two Kalopanax septemlobus individuals (COMPILING COMMITTEE OF ANCIENT AND FAMOUS TREES IN LAOSHAN DISTRICT, 2015, HISTORY AND ANNALS OFFICE OF QINGDAO, 2007).

Some ancient and famous trees carry an agricultural background and get preserved in agricultural communities in Laoshan District. They included those grown by indigenous peoples to harvest fruits, enjoy the transient beauty of flowers, look for shade, make wind/rain shelters, worship, and pray for joy. Examples are G. biloba, Armeniaca vulgaris, Castanea mollissima, Chaenomeles sinensis, Cerasus pseudocerasus, and Punica granatum. Among them, 16 G. biloba individuals are still fruitful. Ancient and famous trees used as offerings were often planted by immigrants from places like Shanxi, Henan, Hebei, and Yunnan during the early Ming Dynasty, to commemorate their settlement or the start of their undertakings in Qingdao, to express nostalgia, or to embellish their clan shrines. Examples are $11 S$. chinensis individuals grown for offerings or prayer, two $S$. japonica in Dongwuyixiang Village, Beizhai Residential District, and $P$. orientalis in Xiaowang Village, Wanggezhuang Residential District (HISTORY AND ANNALS OFFICE OF QINGDAO, 2007).

Among the exotic ancient and famous trees in Laoshan District, ancient trees are in the minority, while famous trees, mostly rare species, are dominant. There are two types of exotic famous trees: the flowering trees introduced during the construction of gardens in Taoist temples, and the exotic species imported in large quantities from other countries by modern colonizers. Examples are Camellia japonica, Trachycarpus fortunei, Machilus thunbergii, and Magnolia grandiflora in the scenic spot Taiqing Temple.

\section{Quantitative characteristics of ancient and famous trees in Laoshan District}

According to surveys, there are a total of 290 ancient and famous trees in Laoshan District, comprising 42 species, 34 genera, and 26 families (Table 1) (COMPILING COMMITTEE OF ANCIENT AND FAMOUS TREES IN LAOSHAN DISTRICT, 2015). The density of ancient and famous trees in the region is 0.7 plants $/ \mathrm{km}^{2}$, which is 6.6 times that in Qingdao City $\left(0.1\right.$ plants $\left./ \mathrm{km}^{2}\right)$ and 243.3 times that in China ( 0.003 plants $\left./ \mathrm{km}^{2}\right)$, indicating abundant ancient and famous trees in the region. The ancient and famous trees in Laoshan District amount to $66.7 \%, 50 \%$, and $45.7 \%$ of the total families, genera, and species of the ancient and famous trees reported in Qingdao City respectively (ZHANG et al., 2017); and $28.9 \%, 16.7 \%$, and $9.1 \%$ of the woody plants in Qingdao City (ZANG, 1992). These results suggested that the ancient and famous trees in Laoshan District constituted a large proportion of the ancient and famous trees in Qingdao City, but a relatively low proportion of the woody plants in Qingdao City, in terms of the numbers of families, genera, and species. In general, the ancient and famous trees in 
Table 1 - Statistics of ancient and famous trees in Laoshan District, Qingdao City.

\begin{tabular}{|c|c|c|c|c|}
\hline Family & Genus & Species & Number of individuals & Percentage $(\%)$ \\
\hline I Ginkgoaceae & 1 Ginkgo & (1) Ginkgo biloba & 74 & 25.5 \\
\hline \multirow{2}{*}{ II Pinaceae } & \multirow{2}{*}{2 Pinus } & (2) Pinus bungeana & 1 & 0.3 \\
\hline & & (3) Pinus densiflora & 4 & 1.4 \\
\hline \multirow{2}{*}{ III Cupressaceae } & 3 Sabina & (4) Sabina chinensis & 16 & 5.5 \\
\hline & 4 Platycladus & (5) Platycladus orientalis & 11 & 3.8 \\
\hline \multirow{4}{*}{ IV Magnoliaceae } & \multirow{4}{*}{5 Magnolia } & (6) Magnolia denudata & 7 & 2.4 \\
\hline & & (7) Magnolia liliflora & 3 & 1.0 \\
\hline & & (8) Magnolia grandiflora & 1 & 0.3 \\
\hline & & (9) Magnolia sieboldii & 1 & 0.3 \\
\hline V Ranunculaceae & 6 Paeonia & (10) Paeonia suffruticosa & 1 & 0.3 \\
\hline VI Lauraceae & 7 Machilus & (11) Machilus thunbergii & 2 & 0.7 \\
\hline VII Lythraceae & 8 Lagerstroemia & (12) Lagerstroemia indica & 8 & 2.8 \\
\hline VIII Punicaceae & 9 Punica & (13) Punica granatum & 6 & 2.1 \\
\hline IX Theaceae & 10 Camellia & (14) Camellia japonica & 13 & 4.5 \\
\hline X Euphorbiaceae & 11 Sapium & (15) Sapium sebiferum & 1 & 0.3 \\
\hline \multirow{4}{*}{ XI Rosaceae } & 12 Chaenomeles & (16) Chaenomeles sinensis & 9 & 3.1 \\
\hline & & (17) Chaenomeles speciosa & 1 & 0.3 \\
\hline & 13 Armeniaca & (18) Armeniaca vulgaris & 2 & 0.7 \\
\hline & 14 Cerasus & (19) Cerasus pseudocerasus & 1 & 0.3 \\
\hline XII Calycanthaceae & 15 Chimonanthus & (20) Chimonanthus praecox & 1 & 0.3 \\
\hline XIII Leguminosae & 16 Sophora & (21) Sophora japonica & 10 & 3.4 \\
\hline XIV Rutaceae & 17 Evodia & (22) Evodia daniellii & 1 & 0.3 \\
\hline XV Buxaceae & 18 Buxus & (23) Buxus sinica & 15 & 5.2 \\
\hline \multirow{3}{*}{ XVI Fagaceae } & \multirow{2}{*}{19 Quercus } & (24) Quercus acutissima & 1 & 0.3 \\
\hline & & (25) Quercus variabilis & 15 & 5.2 \\
\hline & 20 Castanea & (26) Castanea mollissima & 1 & 0.3 \\
\hline \multirow{3}{*}{ XVII Ulmaceae } & 21 Aphananthe & (27) Aphananthe aspera & 2 & 0.7 \\
\hline & \multirow{2}{*}{22 Celtis } & (28) Celtis bungeana & 3 & 1.0 \\
\hline & & (29) Celtis sinensis & 10 & 3.4 \\
\hline XVIII Rhamnaceae & 23 Hovenia & (30) Hovenia dulcis & 1 & 0.3 \\
\hline \multirow[t]{2}{*}{ XIX Aceraceae } & 24 Acer & (31) Acer truncatum & 1 & 0.3 \\
\hline & & (32) Acer buergerianum & 1 & 0.3 \\
\hline $\mathrm{XX}$ Anacardiaceae & 25 Pistacia & (33) Pistacia chinensis & 14 & 4.8 \\
\hline XXI Juglandaceae & 26 Pterocarya & (34) Pterocarya stenoptera & 8 & 2.8 \\
\hline XXII Araliaceae & 27 Kalopanax & (35) Kalopanax septemlobus & 2 & 0.7 \\
\hline XXIII Ebenaceae & 28 Diospyros & (36) Diospyros lotus & 1 & 0.3 \\
\hline \multirow{3}{*}{ XXIV Oleaceae } & 29 Osmanthus & (37) Osmanthus fragrans & 5 & 1.7 \\
\hline & 30 Chionanthus & (38) Chionanthus retusus & 9 & 3.1 \\
\hline & 31 Syringa & (39) Syringa oblata & 1 & 0.3 \\
\hline \multirow{2}{*}{ XXV Bignoniaceae } & 32 Catalpa & (40) Catalpa bungei & 24 & 8.3 \\
\hline & 33 Campsis & (41) Campsis grandiflora & 1 & 0.3 \\
\hline XXVI Palmae & 34 Trachycarpus & (42) Trachycarpus fortunei & 1 & 0.3 \\
\hline \multicolumn{3}{|c|}{ - } & 290 & 100 \\
\hline
\end{tabular}

Laoshan District are relatively diverse in the species composition, compared with those in Qingdao City, woody plants of the natural vegetation included.

Local species constituted a relatively large proportion of the ancient and famous trees currently in Laoshan District; these species are G. biloba,
P. orientalis, S. chinensis, Q. variabilis, Catalpa bungei, Buxus sinica, S. japonica, and C. japonica, which corresponded to $74,11,16,15,24,15,10$, and 13 individuals respectively, with a total of 178 . These eight species account for $19.1 \%$ of the species and $61.4 \%$ of the individuals of all the ancient and 
famous trees in Laoshan District. The species Pinus bungeana, M. grandiflora, Magnolia sieboldii, Paeonia suffruticosa, Q. acutissima, C. mollissima, C. praecox, Syringa oblata, C. sinensis Nakai, Hovenia dulcis, C. pseudocerasus, Acer truncatum, A. buergerianum, Diospyros lotus, Campsis grandiflora, Evodia daniellii, and T. fortunei, have one individual per species (HISTORY AND ANNALS OFFICE OF QINGDAO, 2007). These 17 species account for $40.5 \%$ of the species and $5.9 \%$ of the individuals of all ancient and famous trees in Laoshan District. These results demonstrated that currently in Laoshan District local species are dominant among the ancient and famous trees, and that there is a comparatively small number of both trees originated in the Yangtze River Basin or regions further south, and exotic trees introduced elsewhere.

Age structure of ancient and famous trees in Laoshan District

According to their ages, national ancient trees are classified into national first-class ancient trees (aged 500 years or more), and national thirdclass ancient trees (aged 100-299 years). There is no such classification scheme based on age for national famous trees (NATIONAL AFFORESTATION COMMITTEE OF CHINAAND STATE FORESTRY ADMINISTRATION OF CHINA, 2001). There are $68,40,173$ individuals of national first-, second-, third-class ancient trees respectively, and 9 national famous trees, which make up 23.5\%, 13.8\%, 59.7\%, and $3.1 \%$ of the total number of ancient and famous trees in Laoshan District, correspondingly. National third-class ancient trees account for the highest percentage of the total (Figure 2a). In Qingdao City, there are 247, 175, 651national first-, second-, thirdclass ancient trees, and 171 national famous trees, which constituted $19.9 \%, 14.1 \%, 52.3 \%$, and $13.7 \%$ of the total number of ancient and famous trees in the region respectively (Figure $2 b$ ). Comparison of age structures of the ancient and famous trees showed that there are relatively more national first-class ancient trees in Laoshan District than in Qingdao City.

Among the national first-class ancient

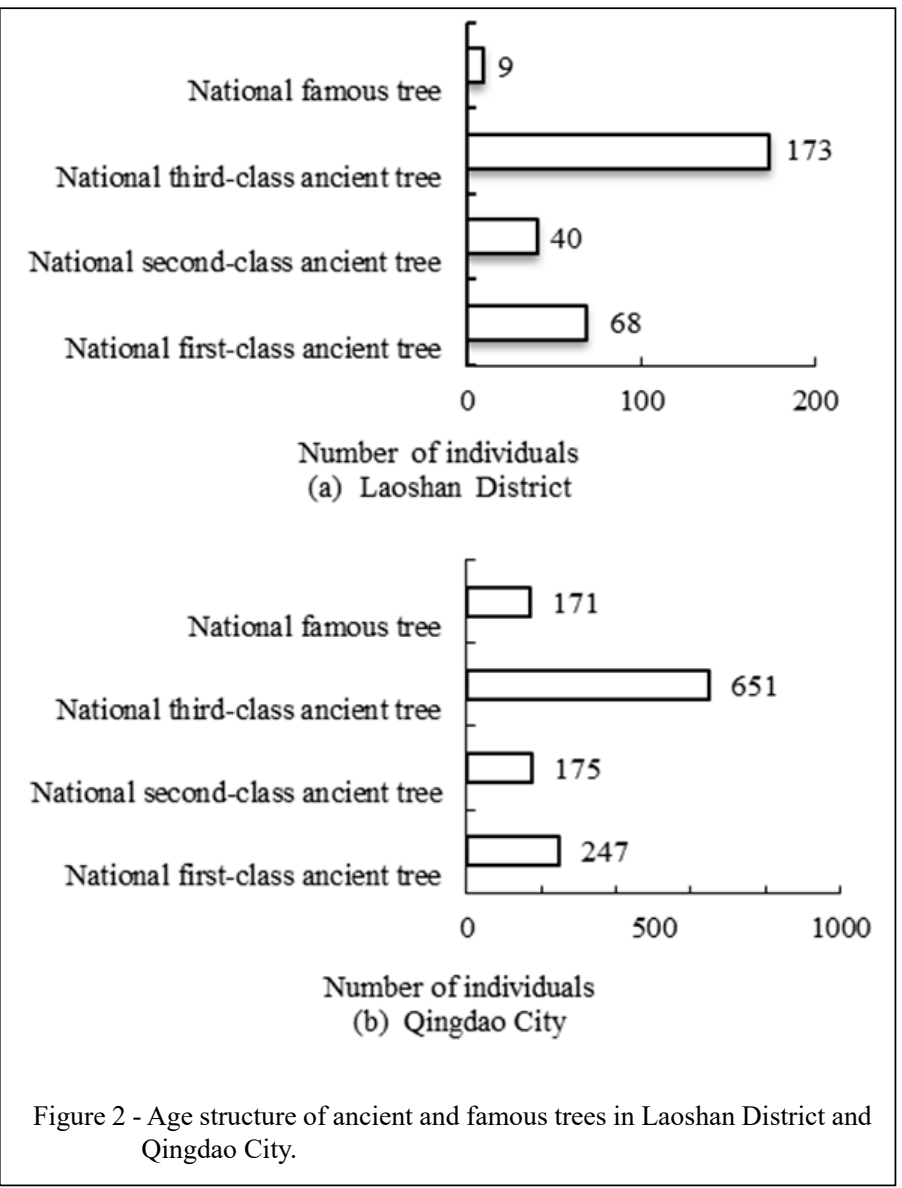

Ciência Rural, v.49, n.10, 2019. 
tress in Laoshan District, G. biloba has the greatest number of individuals (50), which makes up $73.5 \%$ of the total, and also the biggest number (10) of national second-class ancient trees in the region, which accounts for $25 \%$ of the total. This is because G. biloba is naturally long-lived and less susceptible to pests and diseases than other species (LI et al., 2011). Furthermore, it is often planted in the gardens of temples with superior habitat and hence is better preserved and managed in a long period. Among the national third-class ancient trees in the region, $C$. bungei is dominant (24 individuals) and makes up $13.9 \%$ of its class.

There are 20 national first-class ancient trees aged over 1000 years in Laoshan District, including 15 G. biloba, 3 S. chinensis, 1 Aphananthe aspera, and $1 S$. japonica; these trees make up $6.9 \%$ of the total number of ancient and famous trees in Laoshan District. This percentage is higher than that of Qingdao City (2.7\%). The oldest ancient tree in Laoshan District is the $S$. chinensis in the Taiqing Temple. With an age of more than 2150 years, it is also the oldest ancient tree in Qingdao City (COMPILING COMMITTEE OF ANCIENT AND FAMOUS TREES IN LAOSHAN DISTRICT, 2015, HISTORY AND ANNALS OFFICE OF QINGDAO, 2007).

\subsection{Regional distribution and growth condition of ancient and famous trees in Laoshan District}

(1) Distribution of ancient and famous trees in Laoshan District.

Most of the ancient and famous trees in Laoshan District are located in the Laoshan scenic area, whereas the minority are in agricultural communities. There are 225 ancient and famous trees, comprising 36 species, 31 genera, and 23 families in the Laoshan scenic area, which make up $77.6 \%$ of the total number of ancient and famous trees in Laoshan District. These include 54, 26, and 136 national first-, second-, and third-class ancient trees respectively, which account for $79.4 \%, 65 \%$, and $78.6 \%$ of the total numbers of national first-, second-, and third-class ancient trees in Laoshan District. In addition, there are 9 famous trees, comprising 8 species, 7 genera, and 7 families in the Laoshan scenic area; they are $T$. fortunei, $P$. suffruticosa, Magnolia denudata, M. grandiflora, C. praecox, M. thunbergii, Lagerstroemia indica, and Osmanthus fragrans. The ancient trees in the Laoshan scenic area are mainly G. biloba, C. bungei, Q. variabilis, B. sinica, and Pistacia chinensis. In particular, G. biloba (58) has the largest number of individuals, which corresponds to $25.8 \%$ of the total number of ancient trees in the Laoshan scenic area. There are 23 C. bungei, $15 Q$. variabilis, 15 B. sinica, and 14 P. chinensis, which make up $10.2 \%$, $6.7 \%, 6.7 \%$, and $6.2 \%$ of the total number of ancient trees in the Laoshan scenic area respectively. In agricultural communities in Laoshan District, there are 65 ancient trees, comprising 17 species, 16 genera, and 14 families, accounting for $22.4 \%$ of the total number of ancient and famous trees in Laoshan District. Most ancient and famous trees are reported in the Wanggezhuang Residential District, with 29 individuals, comprising 9 species, 9 genera, and 8 families; these account for $10.0 \%$ of the total number of ancient and famous trees in Laoshan District. In the Shazikou Residential District, there are 19 ancient trees, comprising 5 species, 5 genera, and 5 families, making up $6.6 \%$ of the total number of ancient and famous trees in Laoshan District. There are 17 ancient trees, comprising 7 species, 7 genera, and 7 families in the Beizhai Residential District, accounting for $5.9 \%$ of the total (Figure 3 ).

(2) Growth condition of ancient and famous trees in Laoshan District

In general, the ancient and famous trees in Laoshan District are in good condition. In particular, 213 vigorously growing ancient and famous trees constituted $73.4 \%$ of the total. There are 37 and 31 individuals in average- and poor-growth condition respectively, which account for $12.8 \%$ and $10.7 \%$ of the total. There are 9 dying individuals, making up $3.1 \%$ of the total. Ancient trees with heights of 10-20 $\mathrm{m}$ are relatively dominant in Laoshan District, with a total of 134 individuals, and account for $46.2 \%$ of the total number of individuals. The tallest ancient trees are two $30 \mathrm{~m}$ tall G. biloba in front of the Sanguan Hall in the Taiqing Temple. In terms of diameter at breast height $(\mathrm{DBH})$, there are relatively more ancient and famous trees with DBH of 30-60 cm in Laoshan District, the sum of which is 104 , accounting for $35.9 \%$ of the total. The 1000-year-old G. biloba in the Tunshan Kindergarten, Wanggezhuang Residential District, has a DBH of $273.9 \mathrm{~cm}$, making it the ancient tree with the largest DBH. In terms of crown width, there are only 23 individuals with crowns wider than $20 \mathrm{~m}$ but 267 less than $20 \mathrm{~m}$, accounting for $92.1 \%$ of the total (Table 2) (HISTORY AND ANNALS OFFICE OF QINGDAO, 2007). Although, the overall growth condition of ancient and famous trees in Laoshan District is good, cautious conservation measures are necessary since there is a comparatively large number of old national first- and second-class ancient trees. In addition, due to their relative age, deteriorating habitats, anthropogenic damages, and 


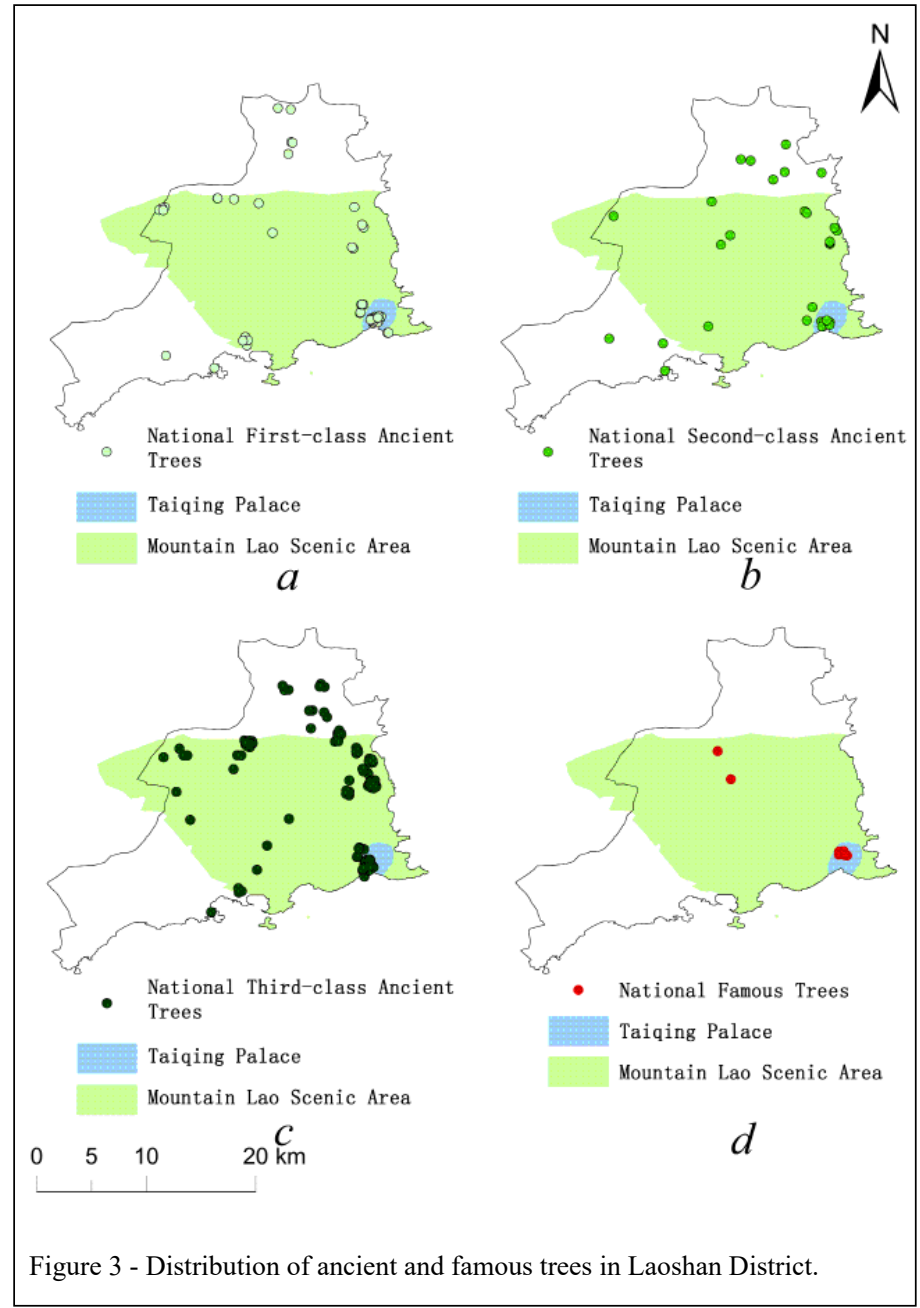

natural hazards, some ancient and famous trees experience poor growth vigor, or are terminally ill.

\section{Characteristics of the floristic composition of ancient} and famous trees in Laoshan District

(1) Family and genus composition of ancient and famous trees in Laoshan District

Flora is a generic term referring to all the plants in a certain community or a specific kind of vegetation in a particular region. Its taxonomic composition and geographic distribution can intuitively reflect the characteristics of the vegetation. Among the flora of the ancient and famous trees of Laoshan District, Rosaceae, Oleaceae, Fagaceae, Ulmaceae, Cupressaceae, Bignoniaceae, Magnoliaceae, Pinaceae, and Aceraceae contain relatively more genera and species. Specifically, Rosaceae consists of 4 species and 3 genera, Oleaceae consists of 3 species and 3 genera, both Ulmaceae and Fagaceae comprise 3 species and 2 genera, both Cupressaceae and Bignoniaceae comprise 2 species and 2 genera, Magnoliaceae contains 4 species and 1 genus, and both Pinaceae and Aceraceae contain 2 species and 1 genus (Table 1). There are 25 species and 17 genera altogether from the 9 aforementioned large families, or relatively large families (which consist of more than 2 species or 2 species respectively). For large families, the numbers of families, constituent genera, and constituent species account for $34.6 \%$, $50 \%$, and $59.5 \%$ of those of ancient and famous trees in Laoshan District respectively. In the flora, Magnolia is the only large genera, with 4 species, whereas Pinus, Chaenomeles, Quercus, Acer, and Trachycarpus are the 5 relatively large genera composed of 2 species. The remaining 28 genera consist of 1 species each (Table 1). These 6 large and relatively large genera make up $17.6 \%$ and $33.3 \%$ of the total number of genera and species of ancient 
Table 2 - Growth condition of ancient and famous trees in Laoshan District.

\begin{tabular}{lccccccc}
\hline Tree height $(\mathrm{m})$ & $\begin{array}{c}\text { Number of } \\
\text { individuals }\end{array}$ & $\begin{array}{c}\text { Diameter at breast } \\
\text { height }(\mathrm{cm})\end{array}$ & $\begin{array}{c}\text { Number of } \\
\text { individuals }\end{array}$ & Crown width $(\mathrm{cm})$ & $\begin{array}{c}\text { Number of } \\
\text { individuals }\end{array}$ & $\begin{array}{c}\text { Growth } \\
\text { vigor }\end{array}$ & $\begin{array}{c}\text { Number of } \\
\text { individuals }\end{array}$ \\
\hline$[30,+\infty)$ & 2 & {$[90,+\infty)$} & 60 & {$[30,+\infty)$} & 1 & vigorous & 213 \\
{$[20,30)$} & 53 & {$[60,90)$} & 87 & {$[20,30)$} & 22 & average & 37 \\
{$[10,20)$} & 134 & {$[30,60)$} & 104 & {$[10,20)$} & 135 & poor & 31 \\
$(0,10)$ & 101 & $(0,30)$ & 39 & $(0,10)$ & dying & 9 \\
\hline
\end{tabular}

and famous trees in Laoshan District respectively. This indicated a diverse species composition, with a relatively high degree of genus diversity and a low degree of family diversity among the flora.

(2) Areal-type composition of ancient and famous tree genera

In China, there are 15 areal-types for spermatophyte genera (WU, 1991). There are 12 areal-types for the 34 genera in the flora of the ancient and famous trees of Laoshan District, Qingdao City (Table 3). Among the flora, 14 genera belong to 3 Temperate areal-types, namely the North Temperate, East Asian \& North American disjunctive, and Old World Temperate areal-types, and they make up $41.2 \%$ of the total number of genera in the flora. Seven genera are categorized into the North Temperate areal-type, accounting for $20.6 \%$ of the total number of genera in the flora. This suggested that there was a relatively large number of temperate genera in the flora of the ancient and famous trees of
Laoshan District, Qingdao City, signifying a certain degree of zonal characteristics. There are 10 genera in the flora belonging to the 5 Tropical areal-types, namely the Pantropic, Old World Tropics, Tropical Asia to Tropical Africa, Tropical Asia \& Tropical Australasia, and Tropical Asia (Indo-Malesia) arealtypes, constituting $29.4 \%$ of the total number of genera in the flora. The areal-type compositions of ancient and famous tree genera in Qingdao City and Laoshan District were compared and it was found that the latter has relatively fewer temperate genera but more tropical genera. Due to the topography of Laoshan District, Qingdao City, the regional oceanic microclimate formed is characterized by abundant precipitation and rare, extreme low temperatures during winter time. As a result, there is less hardship for ancient and famous tree species originating in the tropical zones and there are relatively more ancient and famous trees introduced from the south of the country in Laoshan District. Furthermore,

Table 3 - Areal-types of genera of ancient and famous trees in Laoshan District and Qingdao City.

\begin{tabular}{lcccc}
\hline Areal-type & & & & \\
& Genera & Percentage (\%) & Genera & Percentage (\%) \\
\hline Cosmopolitan & 1 & 2.9 & 1 & 1.5 \\
Pantropic & 5 & 14.7 & 8 & 11.8 \\
\hline Old World Tropics & 1 & 2.9 & 1 & 1.5 \\
Trop. Asia to Trop. Africa & 1 & 2.9 & 1 & 4.5 \\
Tropical Asia \& Trop. Australasia & 1 & 2.9 & 3 & 2.9 \\
Trop. Asia (Indo-Malesia) & 2 & 5.9 & 2 & 26.5 \\
North Temperate & 7 & 20.6 & 18 & 19.1 \\
E. Asia \& N. Amer. disjunctive & 6 & 17.6 & 13 & 5.9 \\
Old World Temperate & 1 & 2.9 & 4 & 2.9 \\
Mediterranean, W. Asia \& C. Asia & 2 & 5.9 & 2 & 14.7 \\
E. Asia & 5 & 14.7 & 10 & 7.4 \\
Endemic to China & 2 & 5.9 & 5 & 100 \\
Total & 34 & 100 & 68 & \\
\hline
\end{tabular}

Ciência Rural, v.49, n.10, 2019. 
among the flora, there are 5 genera belonging to the East Asia areal-type, 2 genera categorized into the Mediterranean, West Asia \& Central Asia areal-type, 2 genera classified as the Endemic to China areal-type, and 1 genus identified as the Cosmopolitan areal-type, accounting for $14.7 \%$, $5.9 \%, 5.9 \%$, and $2.9 \%$ of the total number of genera in the flora respectively.

The Laoshan scenic area in Laoshan District, Qingdao City is a site with diverse plant distributions in Shandong Province. The flora on Laoshan Mountain comprises 1045 species, 517 genera, and 129 families of vascular plants. Numbers of genera classified as the Temperate, Tropical, Cosmopolitan, East Asian, and other areal-types make up $45.7 \%, 24.6 \%, 13.2 \%, 7.9 \%$, and $2.9 \%$ of the total number of genera in the flora respectively (WANG et al., 2001). The areal-type composition of ancient and famous trees genera in Laoshan District, Qingdao City is similar to that of vascular plants in the Laoshan scenic area, in that they are both dominated by temperate genera. However, the percentage of temperate genera in the flora of ancient and famous trees in Laoshan District is slightly lower than that in the flora on Laoshan Mountain. In addition, the percentage of tropical genera in Laoshan District is slightly higher than that on Laoshan Mountain. This suggested that the areal-type composition of ancient and famous tree genera in Laoshan District, Qingdao City has relatively significant tropical characteristics.

\section{DISCUSSION}

As rare natural resources, ancient and famous trees can hardly regenerate into their present size in a short time. The ancient and famous trees in Laoshan District are important in many ways, for example, passing on the history and culture of the region, promoting urban construction of green spaces, developing ecotourism, and protecting regional biodiversity. Currently, ancient and famous tree conservation in Laoshan District is hindered by various issues, such as aging, weakening vitality of the trees (Figure 4), habitat deterioration, natural hazards like droughts and lightning strikes (Figure 5), pests and diseases, low public awareness of conservation, underdeveloped management systems and institutions, and insufficient maintenance grants.

In order to protect ancient and famous trees in Laoshan District, according to the Regulations on Qingdao Ancient and Famous Trees, technical measures have been employed multiple times in recent years to rejuvenate and maintain ancient and famous trees in the region. These included repairing and building tree pits, setting up tree guards, watering, applying fertilizers, injecting

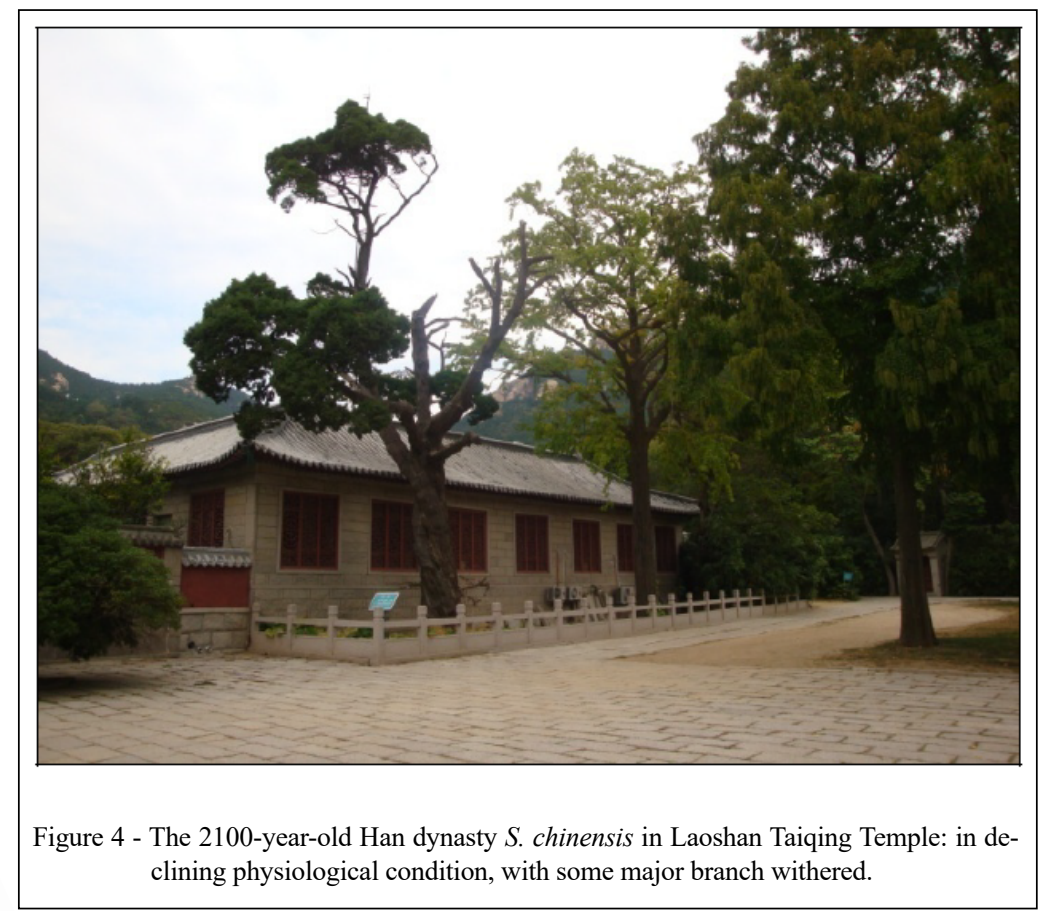

Ciência Rural, v.49, n.10, 2019. 


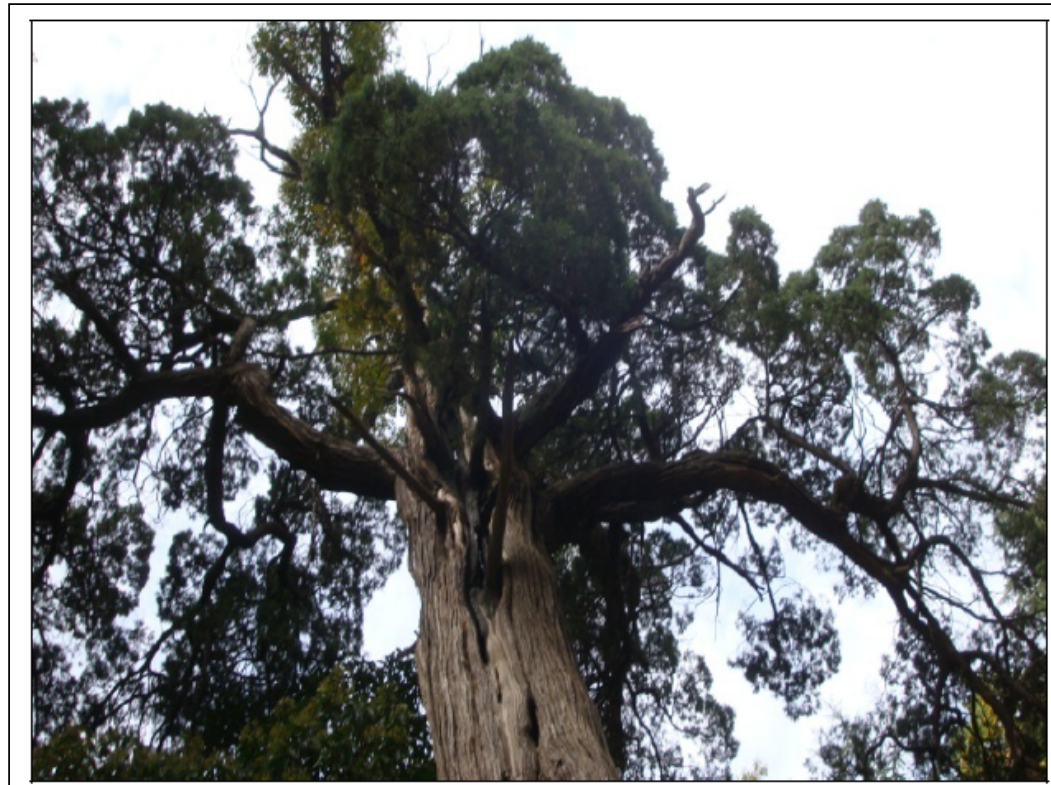

Figure 5 - Influence of lightning strikes on ancient and famous trees in Qingdao City.

Note: The 2150-year-old $S$. chinensis planted by Zhang Lianfu in Laoshan Taiqing Temple, struck by lightning strikes 100 years ago, resulting in the tree hole in the upper part where it was installed a lightning rod.

nutritional fluids, applying medicines against pests and diseases, trimming and pruning, reinforcing tree structures with supports and cables, filling tree holes, reinforcing tree trunks, and installing lightning rods. In 2013, the Laoshan Forest Farm and the Forestry Administration of Laoshan District carried out detailed surveys of ancient and famous trees over the entire region. For each ancient and famous tree, the GPS position was determined and a standard hanging sign was made. A management information system of ancient and famous trees was established, where each ancient and famous tree was registered and tracked in terms of its growth condition, management and maintenance status.

In the future, it will be necessary to first restore the habitats of ancient and famous trees by removing artificial hardened ground or buildings too closed to them, etc. Other measures include strengthening pest and disease controls, improving natural-hazard management, reinforcing routine maintenance and management, strengthening law enforcement, increasing maintenance grants, promoting research into conservation techniques, and regularly inspecting ancient and famous trees. These practices can effectively protect the ancient and famous trees currently reported in Laoshan District. Moreover, an award system and a declaration and registration system should also be established to cultivate and develop follow-up resources. In addition, the ownership system of ancient and famous trees should be reformed to define the responsibilities of ancient and famous tree conservation and management, identifying people in charge.

\section{CONCLUSION}

There are 290 ancient and famous trees, comprising 42 species, 34 genera, and 26 families in Laoshan District. These included four types of ancient and famous trees with different origins, namely religious trees, naturally preserved wild trees, trees with agricultural backgrounds or used as offerings, and exotic trees introduced elsewhere. The ancient and famous trees in Laoshan District are relatively diverse in terms of species and are generally in comparatively good condition. There are relatively more local species, and fewer exotic trees, with a relatively large number of comparatively old ancient trees. Ancient and famous trees have a wider distribution in agricultural communities, but are more

Ciência Rural, v.49, n.10, 2019. 
concentrated in the Laoshan scenic area. Most of the trees belong to temperate genera and only a few fall into the genera of other areal-types. Some technical and management measures have been implemented in Laoshan District to preserve ancient and famous trees. However, a wide range of issues, such as aging, weakening vitality of trees, habitat deterioration, serious impacts of natural hazards and pests and diseases, and ineffective conservation measures, are still present. In the future, effective technical and management measures should be implemented to protect the existing ancient and famous trees.

\section{ACKNOWLEGEMENTS}

This work was supported by the Project of Natural Science Foundation of Shandong Province, China (ZR2016DM11).

\section{DECLARATION OF CONFLICT OF INTERESTS}

The authors declare no conflict of interest. The founding sponsors had no role in the design of the study; in the collection, analyses, or interpretation of data; in the writing of the manuscript, and in the decision to publish the results.

\section{AUTHORS' CONTRIBUTIONS}

Xuliang Zhang and Lihua Wang conceived and designed field survey method. Zheng Liu and Tao Zheng collected data and performed the statistical analyzing of the data. Xuliang Zhang, Xiujun Liu and Lihua Wang performed field surveys, Yinghui Cao prepared the draft of the manuscript. All authors critically revised the manuscript and approved of the final version.

\section{REFERENCES}

AKTER, S. et al. Chryseobacterium formosus sp nov., a bacterium isolated from an ancient tree trunk. Archives of Microbiology, v.197, n.8, p.1011-1017, 2015. Available from: <https://link. springer.com/article/10.1007\%2Fs00203-015-1137-9>. Accessed: Apr. 6, 2018. doi: 10.1007/s00203-015-1137-9.

COMPILING COMMITTEE OF ANCIENT AND FAMOUS TREES IN LAOSHAN DISTRICT. Ancient and famous trees in Laoshan District. Beijing: Chinese Forestry Press, 2015.

GAO, X. F.; ZHANG, X. Q. Integrated control technology of ancient and famous trees' disease and insect pest. Journal of Green Science and Technology, n.17, p.36-37, 39, 2018.

GOUGH, L.A. et al. Specialists in ancient trees are more affected by climate than generalists. Ecology and Evolution, v.23, n.5, p.5632-5641, 2015. Available from: <https://onlinelibrary.wiley. com/doi/full/10.1002/ece3.1799>. Accessed: Apr. 8, 2018. doi: org/10.1002/ece3.1799

HISTORY AND ANNALS OFFICE OF QINGDAO. History and annals of ancient and famous trees in Qingdao City. Qingdao: Ocean University of China Press, 2007.
HISTORY AND ANNALS OFFICE OF QINGDAO. History and annals of Laoshan Mountain. Beijing: Xinhua Press, 1999.

LI, L. et al. Life table of natural Ginkgo biloba population in Tianmu Mountain Nature Reserve. Chinese Journal of Ecology, v.31, n.1, p.53-58. Available from: < http://qikan.cqvip.com// Qikan/Article/Detail?id=36255996> . Accessed: Mar. 8, 2019.

LIU, D.M. et al. A preliminary study on the old and valuable trees in Hong Kong. Ecology and Environment, v.17, n.4, p.15601565, 2008. Available from: <http://qikan.cqvip.com/Qikan/ Article/Detail?id=28233844>. Accessed: Apr. 8, 2018.

JU, C. Y. et al. GIS-based coastal area suitability assessment of geo-environmental factors in Laoshan district, Qingdao. Natural Hazards and Earth System Sciences, v.12, n.1, p.143-150. 2012. Available from: <https://www.nat-hazards-earth-syst-sci.net/12/ 143/2012/ nhess-12-143-2012.pdf $>$. Accessed: Apr. 3, 2019. doi: 10.5194/nhess-12-143-2012.

MARTIN, J. Ancient Trees in the Landscape: Norfolk's Arboreal Heritage. Agriculture History, v.87, n.3, p.419- 420, 2013.

MARRIS, E. Blazes threaten iconic trees. Nature, v.530, n7589 p.137-138, 2016. Available from:< https://www.nature.com/ polopoly fs/1.19308!/menu/main/topColumns/topLeftColumn/ pdf/nature.2016.19308.pdf > . Accessed: Apr. 8, 2018. doi: 10.1038/ nature. 2016. 19308.

MATHAUX, C. et al. Ancient juniper trees growing on cliffs: toward a long Mediterranean tree-ring chronology. Dendrochronologia v.37, p.79-88, 2016. Available from: <https://linkinghub.elsevier. com/retrieve/pii/S1125786515000922>. Accessed: Apr. 8, 2018. doi: 10.1016/j.dendro.2015.12.005.

MCKINNEY, M. L. Urbanization as a major cause of biotic homogenization. Biological Conservation, v.127, p.247-260, 2006. Available from: <https://www.sciencedirect.com/science/ article/pii/S0006320705003563?via\%3Dihub>. Accessed: Apr. 8, 2018. doi: 10.1016/j. biocon.2005.09.005.

MINISTRY OF CONSTRUCTION OF THE PEOPLE'S REPUBLIC OF CHINA. Measures for the administration of the urban ancient and famous trees protection and management, 2000. Available from: <http://www.mohurd.gov.cn/wjfb/200611/ t20061101 157014.html>. Accessed: Oct. 15, 2015.

MOHAMAD, R.S. et al. Economic analysis in organic olive farms: the case of the ancient olive trees in the rural parkland in Apulia. New Meditt, v.12, n.4, p.55-61, 2013. Available from: <http:// www.scopus.com/inward/record.url?eid=2-s2.0-84893417495\&pa rtnerID $=$ MN8TOARS $>$. Accessed: Apr. 8, 2018

NATIONAL AFFORESTATION COMMITTEE OF CHINA AND STATE FORESTRY ADMINISTRATION OF CHINA. Census document technical regulations of national ancient and famous trees, 2001. Available from: <http://wenku.baidu.com/link?url= WLYDle3Zna7dhB9aLTZwGhRz8U7HY11c5a619uM691WzrS az8oG\#\#\#>. Accessed: Oct. 15, 2015.

NUGTEREN, A. The sacred tree: Ancient and Medieval Manifestations. Journal for the Study of Religion Nature and Culture, v.10, n.4, p.500-502, 2016. Available from: $<$ https://journals.equinoxpub.com/index.php/JSRNC/article/ view/31507>. Accessed: Apr. 16, 2018. doi: 10.1558/jsrnc. v10i4.31507. 
WANG, S.Q. et al. Studies on flora of Laoshan Mountain in Shandong Province. Journal of Wuhan Botanical Research, v.19, n.6, p.467-474, 2001. Available from: <http://qikan.cqvip. com/Qikan/Article/Detail?id=6404592>. Accessed: Apr. 16, 2018.

WU, Z.Y. Distribution types of Chinese seed plants at generic level. Acta Botanica Yunnanica, n. sup IV, p.1-139,1991. Available from: $\quad<$ https://max.book118.com/html/2017/0604/111603281. shtm>. Accessed: Apr. 16, 2018.

YUAN, M.; WANG, H.Y. The protection status and file management of ancient and famous trees in rural areas of Laoshan District. Journal of Shandong Agricultural University ( Natural Science Edition ), v.49, n.1, p.53-56, 2018. Available from: $<$ http:/ qikan.cqvip.com/Qikan/Article/ArticleReade?ArticleId=7000521 534\&from=Qikan_Article_Detail $>$. Accessed: Apr. 3, 2019. doi: 10. 3969/j. issn. $1000-232 \overline{4} .2018 .01 .011$.

ZANG, D. K. Woody flora of mount Laoshan. Journal of Shandong Agriculture University, v.23, n.4, p.405.410, 1992. Available from: <http://qikan.cqvip.com/Qikan/Article/Detail?id=851955>. Accessed: Apr. 3, 2019
ZHANG, X.L. et al. The characteristics of ancient and famous trees in Qingdao City, Shandong Province, China and possible conservation measures. Fresenius Environmental Bulletin, v.26, n.3, p.2014-2022, 2017. Available from: <http://apps. webofknowledge.com/full_record.do?product=UA\&search_mode $=$ GeneralSearch \&qid $=3 \& \overline{\mathrm{SID}}=7 \mathrm{ExT}$ trnCINv9AIPWgCc\&page $=1$ $\& d o c=1>$. Accessed: Apr. 16, 2018.

ZHANG, Z.M. et al. Distribution and rejuvenation technology of ancient and famous tree in Beijing. Vegetos, v.26, n.1, p.188-195, 2013. Available from: <http://apps.webofknowledge.com/full record.do?product $=\mathrm{UA} \&$ search_mode $=$ GeneralSearch \&qid $=7 \& \overline{\mathrm{S}}$ $\mathrm{ID}=7 \mathrm{ExT}$ trnCINv9AlPWgCc $\&$ page $=1 \& \mathrm{doc}=1>$. Accessed: Apr. 16, 2018. doi: 10.5958/j.2229-4473.26.1.027.

ZHU, P. et al. Maintenance of genetic diversity in a small, isolated population of ancient tree Erythrophleum fordii. Journal of Systematics and Evolution, v.51, n.6, p.722-730, 2013. Available from: <http://apps.webofknowledge.com/full_record. do product $=$ UA\&search mode $=$ GeneralSearch \&qid $=49 \& \mathrm{SID}=5$ FBC6oxIUYOFmDZLYnu\&page $=1 \&$ doc $=1>$. Accessed: Apr. 16, 2018. doi: 10.1111/jse.12047. 